\title{
Self-mention in argumentative essays written by pre-service teachers of English
}

\section{OLEKSANDR KAPRANOV}

\begin{abstract}
This article presents and discusses a study that aims at establishing how self-mentions are used by pre-service teachers of English as a Foreign Language (EFL) in their argumentative essay writing. The study examined a corpus of argumentative essays written on a range of topics in EFL didactics by a group of pre-service EFL teachers (hereafter - participants). The corpus involved two rounds of argumentative essays written by the participants and their respective controls (nonteacher EFL students). The frequency of self-mentions in the corpus was analysed using the Statistical Package for Social Sciences (IBM 2011) in terms of raw values, and the computer program WordSmith (Scott 2008) as normalised data per 1000 words. The results of the quantitative analysis revealed that the frequency of the self-mention we decreased, whereas the frequency of the self-mention I increased in the second round of essays. These findings and their linguo-didactic implications are further discussed in the article.
\end{abstract}

\section{Keywords}

argumentative essay, English as a Foreign Language (EFL), selfmention 


\title{
Używanie pierwszej osoby w rozprawkach argumentacyjnych pisanych przez studentów kształcących się na nauczycieli języka angielskiego
}

\begin{abstract}
Abstrakt
Artykuł ten przedstawia badania, które mają na celu pokazać, jak studenci - przyszli nauczyciele języka angielskiego jako języka obcego (dalej nazywani uczestnikami) - używaja pierwszej osoby w rozprawkach argumentacyjnych. Badaniom poddano zbiór rozprawek argumentacyjnych poruszających różne tematy. Zbiór ten obejmował dwie serie rozprawek argumentacyjnych napisanych przez uczestników oraz przez studentów niekształcących się na nauczycieli języka angielskiego. Częstotliwość pisania w pierwszej osobie została przeanalizowana za pomoca programu do statystycznej analizy danych (Statistical Package for Social Sciences IBM 2011) w zakresie wartości surowych oraz za pomoca programu WordSmith (Scott 2008) w zakresie danych znormalizowanych. Wyniki analizy ilościowej ukazały, że częstotliwość użycia we 'my' zmalała, podczas gdy częstotliwość użycia $I$ 'ja' wzrosła w drugiej serii pisania rozprawek. Te ustalenia oraz ich językowo-dydaktyczne implikacje zostały omówione w artykule.
\end{abstract}

\section{Słowa kluczowe}

rozprawka argumentacyjna, angielski jako język obcy, pisanie w pierwszej osobie

\section{Introduction}

This article presents and discusses a study that aims at establishing how self-mention is used by pre-service teachers of English as a Foreign Language (EFL) in their argumentative essay writing. According to Hyland (1990: 68), an "argumentative essay is defined by its purpose which is to persuade the reader of the correctness of a central statement". Typically, argumentative essays involve such genre characteristics as the main argument, the counter-argument, and conclusions (Hyland 1990: 68, Yoon 2020). The focus of the present study is on how self- 
mention is employed in argumentative essay writing by pre-service EFL teachers. This study is informed by the definition of self-mention proposed by Hyland (2001), who regards it as such lexical means as "the first person pronouns $I$, me, my, we, us, and our" (Hyland 2001: 211) that constitute one of the pivotal metadiscursive features of academic writing in English which contributes to the writer's authorial presence in an academic text (Hyland 2002: 1110). Following Hyland (2020: 35), the authorial presence in academic writing involves "the extent writers choose to intrude into a text using first person pronouns". Seen as a manifestation of authorial presence, self-mention is theorised to be one of the discursive devices that are involved in the author's stance, i.e. the author's point/points of view in relation to the academic text and its readership (Hyland 2005a, 2005b).

From a theoretical perspective, the present investigation feeds into a well-researched domain of discourse studies that regard self-mention in conjunction with the authorial stance (Davies and Harré 1990) and identity (Ivanič 1998), as well as the discursive expression of self (Mühlhäusler and Harré 1990). In harmony with a seminal publication by Ivanič (1998), the literature points to several representations of authorial identities that are manifested via the self-mention $I$, for instance, $I$ as a representative, a guide, an architect, a recounter of research processes, an opinion-holder, and an originator (Mc-Grath 2016, Tang and John 1999, Wang and Nelson 2012). Seen through the framework of discourse studies, the construal of self-mention is deemed to involve social and cultural aspects of discursive practices (Fairclough 1992, Fløttum 2012). As far as social aspects of discursive practices are concerned, Fløttum (2012) indicates that discursive practices of employing self-mentions are influenced by the genre-related social conventions of a given discourse community. For instance, self-mention tends to be implicit in the academic discourse of the so-called "hard" sciences, whereas it appears to be explicit in the current academic discourse in humanities (Fløttum 2012). Another variable that is involved in the use of self-mention in academic discourse is manifested by cultural aspects of discursive practices (Fair- 
clough 1992). The underlying idea of this assumption is associated with the notion of academic discourse as a culturally situated activity (Castelló and Iñesta 2012: 179). The influence of culture on the discursive use of self-mention can be illustrated by the Anglo-Saxon academic culture that is characterised by the explicit use of self-mention in the first person singular (Wang and Nelson 2012). In contrast, however, Slavic academic writers "rarely use the first-person singular for self-mention and typically use authorial plural (e.g., we) even in the cases of single authorship as a sign of authorial modesty" (Grigoriev and Sokolova 2019: 424).

Whereas the present investigation is related to a broader theoretical framework of discourse studies (Davies and Harré 1990, Fairclough 1992, Fløttum 2012, Ivanič 1998), its focus involves an applied linguistic perspective (see Hyland 2020). Informed by the applied linguistic approach towards self-mention (Hyland 2001), this study aims at discovering new knowledge about how self-mentions are employed by a group of pre-service EFL teachers (hereafter participants) in two rounds of argumentative essays written in academic English. The need for establishing how the participants use self-mention in their argumentative essays is explained by a fairly recent interest in EFL students' genre awareness, academic voice, stance and self-mention, respectively (Helms-Park and Stapleton 2003, Hyland and Shaw 2016, Monsen and Rørvik 2017, Negretti and Kuteeva 2011, Szczygłowska 2020, Walková 2019, Yoon 2017, Zhao 2013). Given that academic writing is a critical skill for pre-service EFL teachers to master (Zhang and Zhan 2020), it seems logical to assume that the use of self-mentions in academic writing by pre-service EFL teachers merits further research. Currently, however, little is known about the discursive means of self-mention in academic writing produced by pre-service EFL teachers (Nijakowska 2013, Torres and Alieto 2019). Moreover, there is insufficient state-of-the-art research that focuses on self-mention in argumentative essays written by pre-service EFL teachers (Abdelrahim and Abdelrahim 2020, Alward 2019). Assuming that research on self-mention in argumentative essays by pre-service 
EFL teachers is underrepresented in the literature, the present study seeks to explore the following two research questions:

RQ1: What is the frequency of self-mentions in a series of argumentative essays written by a group of pre-service EFL teachers?

RQ2: Would there be quantitative differences in the frequency of self-mentions in a series of argumentative essays written by a group of pre-service EFL teachers and their controls (nonteacher EFL students)?

Prior to answering the aforementioned research questions, I will outline the construal of self-mention in academic discourse in section 2 . Then, the review of the literature associated with selfmention in academic writing in EFL settings will be given in section 3. Next, the present study will be introduced and discussed in section 4 of the article. Finally, the article will be concluded with the summary of the major findings of the study and their linguo-didactic implications.

\section{Self-mention in academic discourse}

The construal of self-mention in academic discourse has been thoroughly researched in numerous studies associated with academic writing, academic discourse, and EFL teaching and learning (Abdelrahim and Abdelrahim 2020, Alward 2019, Çandarl1, Bayyurt and Mart1 2015, Fløttum 2005, Hyland 2001, Helms-Park and Stapleton 2003, Ivanič 1998, Monsen and Rørvik 2017, Szczygłowska 2020, Walková 2019, Yoon 2017, Zareva 2013). Self-mention in academic writing is defined as "the use of first person pronouns and possessive adjectives to present propositional, affective and interpersonal information" (Hyland 2005b: 181). The current attention to the construal of self-mention in the literature could be accounted for by the contrast it forms to a traditional view of academic discourse as "objective' and deprived of traces left by the author or by other 
voices" (Fløttum 2005: 35). The traditional view implies that selfmention in academic writing is often avoided. Hyland (2003) expands upon this argument by contending that

The avoidance of self-mention is also supported by those who stress the persuasive authority of impersonality, a means of maximizing the writer's credibility by emphasising objectivity and the collective responsibility of academic endeavour (e.g., Lachowicz, 1981: 111). "Objectivity" in the expression of ideas can thus mean removing oneself from one's arguments and allowing the research to speak directly to the reader in an unmediated way. For this reason, many style manuals and textbooks recommend avoiding personal pronouns in favor of a more anonymous persona. (Hyland 2003: 252)

However, it could be argued that any piece of academic discourse bears the mark of its author, whose presence is manifested by means of self-mention expressions associated with the author's identity (Szczygłowska 2020: 73). In this regard, Zareva (2013) notes that the author's identity is explicitly revealed by the use of first person pronouns and the determiner my, which are conceptualised as "probably the most prominent way of making identity roles visible in discourse" (Zareva 2013: 73). This observation is echoed by Fløttum (2005: 30), who argues that "first person pronouns, metadiscourse and hedging are examples of explicit manifestation of the self" which allows for the identification of the authorial presence. According to Hyland (2003), the use of personal pronouns as a discursive means of explicit self-mention is not fortuitous. It could be regarded as a conscious strategy, which

[...] not only allows writers to clarify the goal and direction of their papers, but also to align themselves with their main position, giving a strong indication of where they stand in relation to the issue under discussion. Once again, this explicitly foregrounds the writer's distinctive contribution and commitment to his or her position. This explicitly persuasive use of self-mention is most obvious where it is used to summarise a viewpoint or make a knowledge claim. (Hyland 2003: 258) 
It follows that self-mention as a form of manifesting authorial identity plays a crucial role in mediating the relationship between the writer and the audience in academic discourse (Hyland 2003). This assumption is supported by Thompson, Morton and Storch (2016: 139), who argue that the need to establish an authorial identity is critical in academic discourse. In accordance with Hyland (2003), the use of self-mention in academic discourse demonstrates the authors' familiarity with the rhetorical conventions in their disciplines. Additionally, selfmention in academic discourse facilitates the acknowledgement of the reader's presence (Hyland 2005a), thus contributing to the positive reception of the academic writing. Following Hyland's approach (2008), it appears possible to regard self-mention as a means of creating a shared discursive space between the author and the reader, since it "sets up a dialogue between equals in which the potential point of view of the reader is woven into the fabric of the argument" (Hyland 2005a: 98).

The present study is embedded in Hyland's (2001, 2002, 2003, 2005a, 2005b, 2008) view of self-mentions as a part of the authorial presence that "concerns the extent to which the writer chooses to project himself or herself into the text" (Hyland 2008: 7). In an academic text, self-mentions are involved in the projection of authorial presence upon the following elements: i) statements of purpose, ii) results and claims, and iii) presentation and discussion of the argument (Hyland 2002). It should be mentioned that the authorial presence is comprised of selfmentions, hedges, boosters, and attitude markers, whose use represents a conscious choice on the part of an academic writer to adopt a particular stance and genre-appropriate identity (Hyland 2005b: 181). In line with Hyland (2005b), it is argued in the current literature that self-mentions pertain to interactional metadiscourse that function to secure the reader's attention and focus in the text (Ho and Li 2018, Szczygłowska 2020, Walková 2019). From this perspective, self-mention reflects "the degree of author presence in terms of the incidence of first person pronouns and possessives" (Hyland and Tse 2004: 170). To reiterate, self-mentions involve the academic writer's use of first 
person pronouns and possessive adjectives to present propositional, affective and interpersonal information in order to impart "how they stand in relation to their arguments, their discipline, and their readers" (Hyland 2005b: 181).

\section{Self-mention in academic writing in EFL settings: Literature review}

As outlined in section 2 of the article, self-mention is a construal that is amply elucidated in the literature associated with academic writing in English (Fløttum 2012, Hyland 2001, Ivanič 1998, McGrath 2016, Szczygłowska 2020, Walková 2019) and applied linguistics (Abdelrahim and Abdelrahim 2020, Alward 2019, Çandarlı, Bayyurt and Mart1 2015, Helms-Park and Stapleton 2003, Ho and Li 2018, Monsen and Rørvik 2017, Veličković and Jeremić 2020, Yoon 2017, Zareva 2013, Zhao 2013). The meta-analysis of the literature seems to suggest two contrastive approaches to self-mention in academic writing in EFL settings. The first approach is indicative of self-mention as a genre-dependent element of authorial identity that should be taught to an EFL student writer (Abdelrahim and Abdelrahim 2020, Alward 2019, Çandarl1, Bayyurt and Mart1 2015, Ho and Li 2018, Monsen and Rørvik 2017, Veličković and Jeremić 2020, Zareva 2013). Another approach is suggestive of the epiphenomenal role of self-mention as a discursive feature, since it does not seem to correlate with the quality of academic writing in EFL settings and, subsequently, does not need to be taught (HelmsPark and Stapleton 2003, Yoon 2017, Zhao 2013).

It is inferred from the studies conducted by Abdelrahim and Abdelrahim (2020), Ho and Li (2018), Monsen and Rørvik (2017), Veličković and Jeremić (2020), and Zareva (2013) that self-mentions are involved in the authorial identity of an EFL student writer in terms of the genre convention of academic writing. Specifically, Zareva (2013) analyses the self-mentions I, me, my in the corpus of written and oral presentations in order to discover how the use of these self-mentions is influenced by the genre conventions of academic English. Zareva (2013) has established 
that self-mentions are used by EFL student writers to be able to project their authorial identity upon the genre of academic writing. Zareva (2013) indicates that self-mentions seem to be associated with the following roles of authorial identities, e.g. i) genre roles typical of academic writing, ii) socially-motivated roles, and iii) speech event roles. Additionally, it is inferred from Zareva (2013) that instructional attention to the teaching of self-mention in EFL settings would be desirable.

Similarly to Zareva (2013), Abdelrahim and Abdelrahim (2020) argue that self-mention and other discursive features should be taught explicitly. This argument is supported by the study carried out by Ho and Li (2018), who indicate that selfmentions constitute a frequent metadiscursive feature in academic writing by EFL student writers. Subsequently, Ho and Li (2018: 65) posit that "direct and explicit teaching and learning of metadiscourse should be introduced and encouraged at secondary education and at the early stage of tertiary education". Concurrently with this assumption, Ho and Li (2018) suggest that self-mentions seem to pertain to the authorial identity of an EFL student writer.

The study conducted by Veličković and Jeremić (2020) seems to support Abdelrahim and Abdelrahim (2020), and $\mathrm{Ho}$ and $\mathrm{Li}$ (2018) by claiming that genre-appropriate use of self-mentions should be addressed in teaching academic writing to EFL student writers. However, in contrast to Ho and Li (2018), Veličković and Jeremić (2020) have found that the participants in their study used explicit self-mentions in moderation. Instead, the participants in the study maintained the overall objective tone of academic essays by means of minimising self-mentions and making frequent use of indefinite and impersonal constructions in combination with the passive voice (Veličkovic and Jeremić 2020). Analogously to Veličković and Jeremić (2020), Çandarl1, Bayyurt and Mart1 (2015) demonstrated that $I$ as a self-mention is nearly absent in the corpus of argumentative essays written by Turkish L1 EFL student writers. In particular, Çandarl1, Bayyurt and Martı (2015) reported that there were no instances of $I$ in the majority of argumentative essays written by 
the participants in that study. These findings are interpreted by Çandarl1, Bayyurt and Mart1 (2015) as the Turkish L1 EFL student writers' avoidance of $I$ in their academic writing in English. Whereas Çandarlı, Bayyurt and Martı (2015), and Veličković and Jeremić (2020), respectively, point to the moderate use of self-mentions by the EFL student writers, Alward (2019) reports an excessive use of self-mentions expressed by the first person pronouns in argumentative writing by Arabic L1 EFL student writers. However, the overuse is argued to correlate with the proficiency levels, e.g. EFL student writers at a high proficiency level tend to use first person pronouns less than the students at the beginner and intermediate proficiency levels. The findings reported by Alward (2019) are commensurate with the results of the quantitative analysis in the study conducted by Monsen and Rørvik (2017). Notably, Monsen and Rørvik (2017) indicate that the participants in their study extensively employ $I$ and we in academic writing in English.

In contrast to the aforementioned studies, Zhao (2013), Yoon (2017), Helms-Park and Stapleton (2003) suggest that self-mention as an aspect of the authorial voice is epiphenomenal in academic writing by EFL students. In particular, Helms-Park and Stapleton (2003) argue that the author's presence, which is manifested by self-mentions and other discursive means, does not correlate with the quality of the EFL student writing. HelmsPark and Stapleton (2003) suggest that self-mentions are of little consequences to the quality of EFL writing, since

there may not be a connection between the linguistic and rhetorical devices commonly associated with individualized voice (e.g., first person singular or intensifiers) and the quality of writing, at least within some genres and at some levels of writing proficiency. (Helms-Park and Stapleton 2003: 245)

Helms-Park and Stapleton's (2003) observation is echoed by Zhao (2013), who measures the authorial voice in argumentative writing by Chinese L1 EFL student writers. Whilst the authorial self-mention in the corpus of argumentative essays is 
interpreted by Zhao (2013) as the writer's voice and presence, she concurs with Helms-Park and Stapleton (2003) that these construals tend to be impressionistic and challenging to quantify. Notably, Yoon (2017) arrives at similar conclusions by means of studying self-mentions and authorial voice in the corpus of argumentative essays written by Greek L1 EFL student writers. In the study by Yoon (2017), the quantity and diversity of the authorial voice are examined by means of the Authorial Voice Analyzer (AVA), a computer program that is based on the categories from Hyland's (2002) authorial voice model. Yoon (2017) suggests that whilst self-mentions contribute to the authorial voice strength, there is a weak correlation between the authorial voice and essay quality.

As evident from the literature review, there is a burgeoning line of research in applied linguistics and EFL studies that examines the use of self-mention in argumentative essays written by EFL student writers (Alward 2019, Çandarl1, Bayyurt and Mart1 2015, Ho and Li 2018, Helms-Park and Stapleton 2003, Zhao 2013). Whereas the focus on self-mention in argumentative essay writing appears to be an extensively researched agenda (Helms-Park and Stapleton 2003), there is little research that aims at establishing how self-mentions are used in argumentative essays written by pre-service EFL teachers. Moreover, there are no state-of-the-art studies that aim at contrasting the use of self-mentions in argumentative essays written by pre-service EFL teachers and non-teacher EFL students at the same level of EFL proficiency. In the following section of the article, I will present and discuss the study which seeks to address this under-researched issue. 


\section{The present study}

The present study was a part of a larger research project that sought to explore the use of micro-discursive means, such as discourse markers, in argumentative essay writing produced by pre-service teachers of English (see Kapranov 2019). The study was contextualised within a university course in EFL didactics that was offered at a regional university in Norway. The course design involved an overview of EFL didactics for pre-service EFL teachers. The course, however, was open to non-teacher students enrolled in a yearlong course in English. The course in EFL didactics was based on the book English Teaching Strategies written by Drew and Sørheim (2016).

The course in EFL didactics involved two rounds of argumentative essay writing, the first round of essays (further in the article - E1) and the second round of essays (henceforth - E2). Each argumentative essay was expected to be approximately 1200 words in length. During the course, the students were explicitly taught the principles of argumentative essay writing that addressed genre characteristics, structure, academic vocabulary associated with academic writing in English, and the use of micro-discursive elements in the essay writing, such as discourse markers, boosters and hedges, and self-mentions. Whereas written feedback was provided by the course teacher after the first round of essays (E1), the second round of essays (E2) was meant to be written by the students without any direct involvement of the course teacher. It was assumed that the students would transfer their essay writing skills that they acquired during their E1 writing to their E2 writing.

Given that the course involved the teacher's feedback on E1 and the expectations that the feedback would be transferred to E2, it would be relevant to explore whether or not there would be changes in the use of self-mentions contrasted between these two rounds of essays. The study further presented in the article addressed this scientific query. In addition, the present study involved two specific research questions, which were mentioned in the introduction: (i) the frequency of self-mention employed 
by the participants in their argumentative essays and (ii) possible quantitative differences in the frequency of self-mentions in argumentative essays written by the participants (pre-service EFL teachers) and the control group that was composed of nonteacher EFL students.

\subsection{Participants}

In total, ten participants and ten controls took part in the study that was conducted at a regional university in Norway. The group of participants was composed of eight females and two males, mean age $=24$ y.o., standard deviation $(\mathrm{SD})=9$. All of the participants, as well as the control group, attended the course in EFL didactics at the same university. The controls were matched with the participants in terms of their gender and age demographics, so that the control group consisted of eight females and two males, mean age 26 y.o. ( $S D=6.7)$. Based upon the participants' and controls' secondary school leaving certificates, their English proficiency was estimated to be B1/B2 level according to the "Common European Framework of Reference for Languages" (Council of Europe 2011). There were no English L1 speakers among the participants and their respective controls. The participants and controls signed a consent form allowing the author of the article to use their argumentative essays for scientific purposes. To ensure confidentiality, the real names of the participants were coded as P1, P2, .., and P10 (i.e., the Participant and the number). The identical procedure was applied to the controls, whose real names were coded as C1, C2, $\ldots$, and $\mathrm{C} 10$, respectively.

\subsection{Procedure and method}

The following procedure was used in the study. First, the participants and their controls were provided with the essay template and detailed instructions on how to write an argumentative essay. The template involved a series of moves that were expected in a typical argumentative essay, e.g. the main argu- 
ment, the counter-argument, and conclusions (Hyland 1990). After the participants and their controls attended several seminars on argumentative essay writing, they were asked to write the first round of essays, E1, on a topic in EFL didactics within the time frame of one month. The participants and the control group received detailed written feedback from the course teacher as far as the content and the form of the essay were concerned. Thereafter, the participants and their respective controls were instructed to write the second round of essays, E2. Analogously to E1, E2 had to be on a topic in EFL didactics and had to be written in academic English. As with E1, the E2s were expected to be completed within one month.

Methodologically, the present study was based upon the definition of self-mention formulated by Hyland (2001), who posited that self-mentions were represented by "the first person pronouns I, me, my, we, us, and our" (Hyland 2001: 211) that were employed by an academic writer to persuade the readers and to create a sense of the authorial presence (Hyland 2005a, 2008). Informed by Hyland's (2001) definition of self-mention, the following forms of self-mention were considered in the study: I, me, my, mine, we, our, ours, and us.

The methodology of data analysis involved the following steps. First, the instances of self-mention were manually identified by the author of the article in the participants' and controls' essays (E1 and E2, respectively). Those instances were converted into numerical representations and computed in the Statistical Package for Social Sciences, or SPSS (IBM 2011) as raw data, i.e. no cut-off was used and no normalisation was applied to the data. The means and standard deviations of self-mentions were computed in SPSS (IBM 2011) per group. Third, E1 and E2, respectively, were processed in the computer program WordSmith (Scott 2008) in order to establish the frequency of self-mentions per 1000 words per group. 


\subsection{Corpus}

The corpus of the present study was comprised of E1 and E2 (with a total number of words in all essays $=48,652$ ) written by the participants and their controls, respectively. The descriptive statistics involving means $(\mathrm{M})$ and standard deviations (SD) were computed in SPSS and summarised in Table 1.

Table 1

The descriptive statistics of the corpus

\begin{tabular}{|c|l|c|c|}
\hline $\mathrm{N}$ & \multicolumn{1}{|c|}{ Descriptive Statistics } & Participants & Controls \\
\hline 1 & Total number of words in E1 & 13,324 & 10,263 \\
\hline 2 & M words in E1 & 1,322 & 1,291 \\
\hline 3 & SD in E1 & 116 & 120 \\
\hline 4 & Total number of words in E2 & 12,219 & 12,846 \\
\hline 5 & M words in E2 & 1,222 & 1,386 \\
\hline 6 & SD in E2 & 247 & 381 \\
\hline
\end{tabular}

\subsection{Results}

In total, 169 self-mentions were identified in the first round of essays $(\mathrm{N}=66$ in $\mathrm{E} 1$ written by the participants and $\mathrm{N}=103$ in E1 written by the controls, respectively) and 144 instances of self-mention in the second round of essays ( $\mathrm{N}=68$ in E2 written by the participants and $\mathrm{N}=76$ in E2 written by the controls). The results of the analysis of the raw data (i.e., non-normalised data) in SPSS (IBM 2011) are presented in Table 2. The results include means $(\mathrm{M})$ and standard deviations (SD) per group in the two rounds of argumentative essays.

The normalised frequency of self-mentions per 1000 words that was computed by means of using the software program WordSmith (Scott 2008) is summarised in Table 3. 
Table 2

Means and standard deviations of self-mentions as non-normalised data

\begin{tabular}{|c|c|c|c|c|c|}
\hline $\mathrm{N}$ & $\begin{array}{c}\text { Self- } \\
\text { Mention }\end{array}$ & $\begin{array}{l}\text { Participants } \\
\text { in E1 }\end{array}$ & $\begin{array}{l}\text { Controls } \\
\text { in } \mathrm{E} 1\end{array}$ & $\begin{array}{l}\text { Participants } \\
\text { in E2 }\end{array}$ & $\begin{array}{c}\text { Controls } \\
\text { in E2 }\end{array}$ \\
\hline 1 & I & $\begin{array}{c}\mathrm{M} 4.1 \\
(\mathrm{SD} 3.2)\end{array}$ & $\begin{array}{c}\text { M 5.9 } \\
(\mathrm{SD} 2.1)\end{array}$ & $\begin{array}{c}\text { M 4.3 } \\
\text { (SD 2.8) }\end{array}$ & $\begin{array}{c}\text { M 5.6 } \\
\text { (SD 3.4) }\end{array}$ \\
\hline 2 & $\mathrm{Me}$ & $\begin{array}{c}\text { M O } \\
(\mathrm{SD} 0)\end{array}$ & $\begin{array}{c}\text { M O } \\
(\mathrm{SD} 0)\end{array}$ & $\begin{array}{c}\text { M O } \\
(\mathrm{SD} 0)\end{array}$ & $\begin{array}{c}\mathrm{M} \mathrm{O} \\
(\mathrm{SD} 0)\end{array}$ \\
\hline 3 & My & $\begin{array}{c}\text { M } 1.5 \\
(\mathrm{SD} 0.9)\end{array}$ & $\begin{array}{c}\text { M 2 } \\
\text { (SD 0.7) }\end{array}$ & $\begin{array}{c}\text { M } 2 \\
(\mathrm{SD} 0.7)\end{array}$ & $\begin{array}{c}\text { M } 1.2 \\
\text { (SD } 0.4)\end{array}$ \\
\hline 4 & Mine & $\begin{array}{c}\text { M O } \\
(\mathrm{SD} 0)\end{array}$ & $\begin{array}{c}\text { M O } \\
(\mathrm{SD} 0)\end{array}$ & $\begin{array}{c}\text { M O } \\
(\mathrm{SD} \mathrm{O})\end{array}$ & $\begin{array}{c}\text { M O } \\
(\mathrm{SD} 0)\end{array}$ \\
\hline 5 & $\mathrm{We}$ & $\begin{array}{c}\text { M 5 } \\
\text { (SD 2.9) }\end{array}$ & $\begin{array}{c}\text { M } 5.7 \\
(\mathrm{SD} 4.2)\end{array}$ & $\begin{array}{c}\text { M } 2.8 \\
\text { (SD 1.3) }\end{array}$ & $\begin{array}{c}\text { M } 2.6 \\
\text { (SD 1.5) }\end{array}$ \\
\hline 6 & Our & $\begin{array}{c}\text { M 1 } \\
(\mathrm{SD} 0)\end{array}$ & $\begin{array}{c}\text { M } 1 \\
(\mathrm{SD} 0)\end{array}$ & $\begin{array}{c}\text { M } 1 \\
(\mathrm{SD}\end{array}$ & $\begin{array}{c}\text { M O } \\
(\mathrm{SD} 0)\end{array}$ \\
\hline 7 & Ours & $\begin{array}{c}\mathrm{M} \mathrm{O} \\
(\mathrm{SD} 0)\end{array}$ & $\begin{array}{c}\mathrm{M} \mathrm{O} \\
(\mathrm{SD} 0)\end{array}$ & $\begin{array}{c}\mathrm{M} \mathrm{O} \\
(\mathrm{SD} 0)\end{array}$ & $\begin{array}{c}\text { M O } \\
(\mathrm{SD} 0)\end{array}$ \\
\hline 8 & Us & $\begin{array}{c}\text { M O } \\
(\mathrm{SD} 0)\end{array}$ & $\begin{array}{c}\text { M } 1.5 \\
(\mathrm{SD} 0.5)\end{array}$ & $\begin{array}{c}\text { M } 1 \\
(\mathrm{SD}\end{array}$ & $\begin{array}{c}\text { M O } \\
(\mathrm{SD} 0)\end{array}$ \\
\hline
\end{tabular}

Table 3

The frequency of self-mentions as normalised data per 1000 words

\begin{tabular}{|l|l|c|c|c|c|}
\hline $\mathrm{N}$ & $\begin{array}{c}\text { Self- } \\
\text { Mention }\end{array}$ & $\begin{array}{c}\text { Participants } \\
\text { in E1 }\end{array}$ & $\begin{array}{c}\text { Controls } \\
\text { in E1 }\end{array}$ & $\begin{array}{c}\text { Participants } \\
\text { in E2 }\end{array}$ & $\begin{array}{c}\text { Controls } \\
\text { in E2 }\end{array}$ \\
\hline 1 & I & $0.4 \%$ & $0.5 \%$ & $0.4 \%$ & $0.6 \%$ \\
\hline 2 & Me & 0 & 0 & 0 & 0 \\
\hline 3 & My & $0.1 \%$ & $0.1 \%$ & $0.1 \%$ & $0.1 \%$ \\
\hline 4 & Mine & 0 & 0 & 0 & 0 \\
\hline 5 & We & $0.5 \%$ & $0.5 \%$ & $0.2 \%$ & $0.3 \%$ \\
\hline 6 & Our & $0.01 \%$ & $0.01 \%$ & $0.01 \%$ & 0 \\
\hline 7 & Ours & 0 & 0 & 0 & 0 \\
\hline 8 & Us & 0 & $0.01 \%$ & $0.01 \%$ & 0 \\
\hline
\end{tabular}




\subsection{Discussion}

As previously mentioned in the introduction, the present study involves two research questions that are associated with (i) the frequency of self-mentions in the participants' argumentative essays (RQ1) and (ii) the quantitative differences in the frequency of self-mentions in argumentative essays written by the participants and their controls (RQ2). These research questions will be addressed in detail in the subsections 4.5.1 and 4.5.2 of this article. In addition, I will discuss the changes in the participants' use of self-mentions contrasted between the two rounds of essays (E1 and E2) in subsection 4.5.1.

\subsubsection{The frequency of self-mentions in the participants' argumentative essays}

As far as the first research question is concerned, the results of the data analysis indicate that the most frequent self-mention in the participants' $\mathrm{E} 1$ is we $($ Mean $=5$, standard deviation $=$ 2.9 , the normalised frequency per 1000 words $=0.5 \%$ ), whereas in E2 the participants make the most frequent use of the selfmention $I$ (Mean $=4.3$, standard deviation $=2.8$, the normalised frequency per 1000 words $=0.4 \%$ ). These findings are illustrated by Figure 1. 


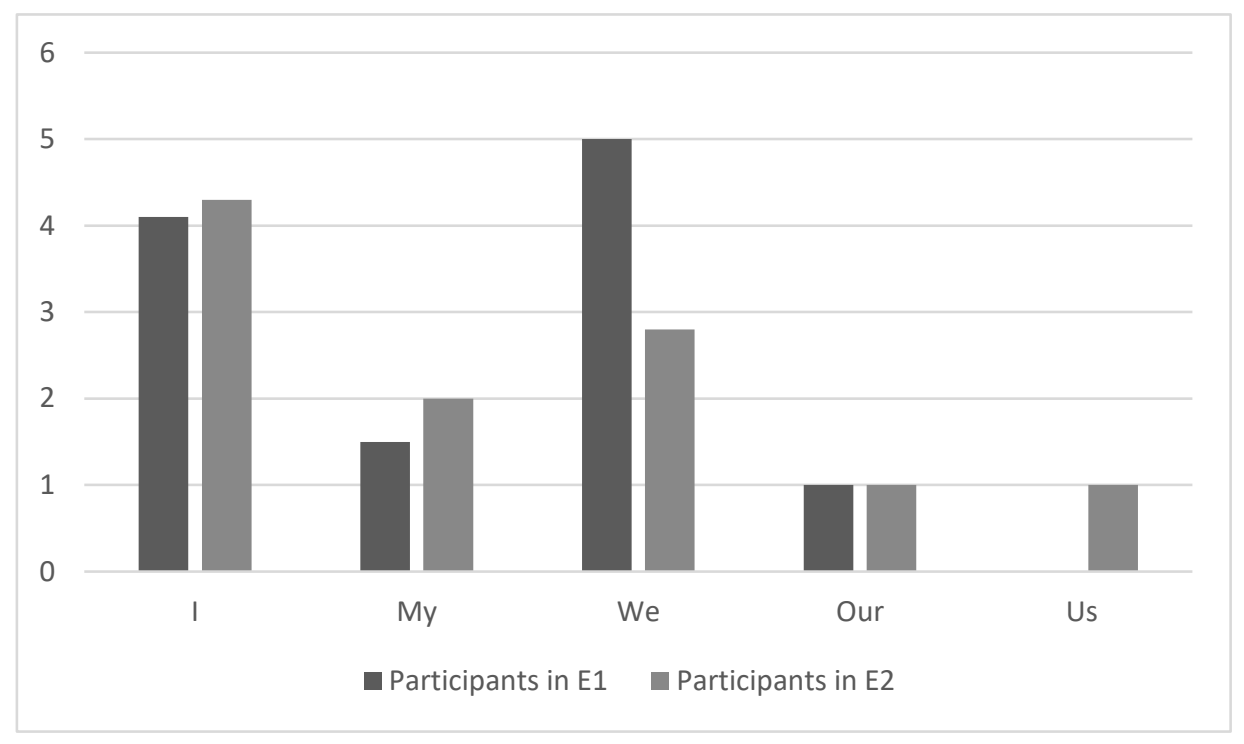

Figure 1

The participants' self-mentions in E1 and E2

The application of the paired sample t-test reveals that the selfmention $I$ is similarly distributed between E1 and E2. Specifically, the results of the t-test indicate that the difference of the distribution of $I$ was not significant at $p<0.05[t(1)=-0.63$, $p=.30]$. Analogously to the self-mention $I$, the results of the paired sample t-test indicated that the distribution of the selfmention we was similar in E1 and E2. Namely, the results of the t-test were not significant at $p<0.05[t(1)=-0.64, p=.29]$. In addition, the results of the data analysis revealed that the self-mentions me, mine, and ours were not used by the participants in all rounds of argumentative essay writing.

A possible explanation of the frequent use of the self-mention we in $\mathrm{E} 1$ by the participants (see Figure 1 and Tables $2-3$ ) could be offered by the suggestion that they use we as an index of the formal register of the English language. The possibility of this explanation is supported by the participants' essays, where they seek to present a credible and formal authorial voice, as illustrated by excerpt (1) below: 
(1) The initial task in this essay was receptive skills versus productive skills in English as a Foreign Language (EFL). However, we believe that these two skills cannot be taught without each other. They complement each other by giving different aspects of the language and that the best solution for the students is a fine balance between the two skills. (Participant P4)

It follows from (1) that the self-mention we is embedded in the formal narrative that is associated with the presentation of the main argument in the essay. The self-mention we appears to be concomitant with the participant's attempt to render the main argument in the formal register of the English language. In this regard, it should be reiterated that Hyland (2002) refers to the self-mention we as a manifestation of the authorial presence that excludes the reader, thus imparting to the writer a sense of authority and credibility. Presumably, the frequent use of we by the participants in E1 serves the purpose of authority and/or credibility in the sense posited by Hyland (2002).

Whereas the results of the data analysis indicate that we is the most frequently used self-mention in E1, the distribution of this self-mention among the participants' E1 was not uniform, as exemplified by Figure 2 .

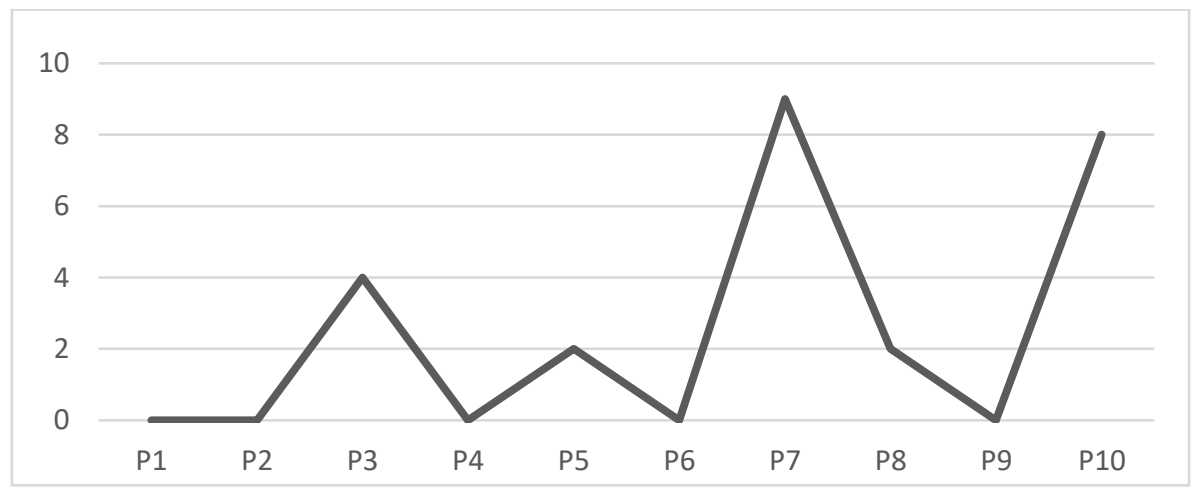

Figure 2

The distribution of the self-mention we in the participants' $\mathrm{E} 1$ 
As evident from Figure 2, the use of we was within the range from $\mathrm{N}=0$ in the essays written by participants P1, P4, P6 and P9 to $N=9$ in the essay written by P7. Similarly, the self-mention we was not equally distributed in the participants' E2 essays. These findings are in line with the recent literature (Monsen and Rørvik 2017) that reports an uneven distribution of selfmentions in the corpus of essays produced by EFL student writers. Specifically, Monsen and Rørvik (2017) indicate that Norwegian L1 EFL students vary the use of self-mentions so that

some are used infrequently by a few writers, while at the other end of the scale we find pronouns used by most of the writers, if not always very frequently. Briefly, the most infrequently used pronouns are 'my', 'your', 'us', 'own', and 'ourselves', whereas the most frequently used are the first-person pronouns 'I' and 'we'. (Monsen and Rørvik 2017: 98)

The findings in the present study seem to support the investigation conducted by Monsen and Rørvik (2017). However, in contrast to Monsen and Rørvik (2017), the novel finding in the present investigation involves the following. Whilst we was the most frequent self-mention in the participants' $\mathrm{E} 1$, it was less frequent in E2 (see Tables 2 - 3). In E2, the most frequent selfmention appears to be $I$ (Mean $=4.3$, standard deviation $=2.8$, the normalised value per 1000 words $=0.4 \%$ ).

A possible explanation for the increased frequency of the selfmention $I$ in the participants' E2s could be a tendency to employ a more neutral and, perhaps, more colloquial register of the English language in the second round of essays. This suggestion seems to be supported by multiple instances of the participants' use of the less formal register of English in contrast to E1, as exemplified by excerpt (2):

(2) There are many different ideologies behind the why, how and when these skills should be obtained. Another thing I cannot ignore is how they should be compared to each other. I believe that throughout the previous centuries many changes have taken place and they have influenced many points of view. 
I don't believe however that the opinions represented in this essay are conclusive and are the sole truths. My opinion is $\boldsymbol{m y}$ own and it is possible that it will change when new developments and new information will be presented in the future. I believe the main argument with which this essay started is insufficient and just plain wrong. (P1)

As observed in (2), the presence of the self-mention I appears to be embedded in a seemingly less academically rigorous narrative that is characterised by the participant's reflections, rather than a well-structured and logical argument. Stylistically, (2) could be classified as a neutral and, presumably, colloquial piece of writing due to the contractions, unnecessary and repetitive foregrounding of the authorial voice that appears to be explicitly subjective, e.g. "my opinion is $\mathbf{m y}$ own" and "I believe", respectively. Notably, the frequency of the self-mention $I$ increases concurrently with the more frequent use of $m y$ in E2, in contrast to E1, as seen in Figure 3.

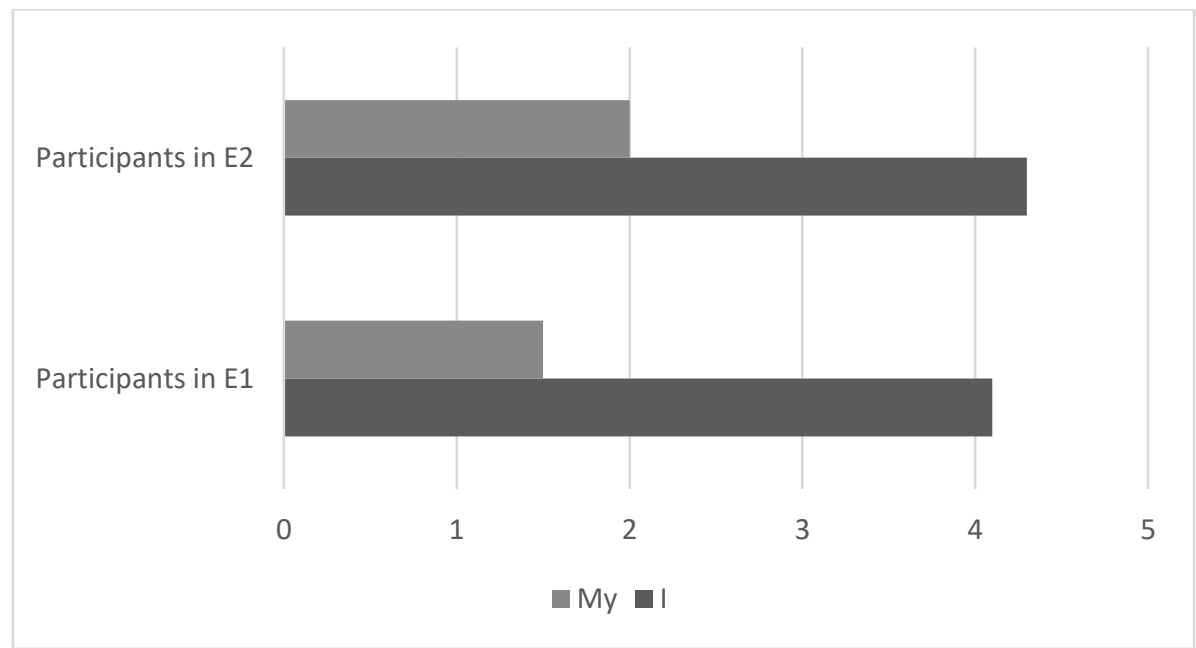

Figure 3

The frequency of the participants' use of the self-mentions $I$ and $m y$ in E1 and E2 
It could be assumed that the increased frequency of the selfmentions $I$ and $m y$ in E2 imparts a more personal and reflective tonality to the participants' essays. This assumption is further illustrated by excerpt (3). In (3), we can observe the co-occurrence of the self-mentions $I$ and $m y$ :

(3) With the end of the essay at hand, I hope I have managed to persuade some of the readers to agree with $\boldsymbol{m y}$ point of view on the topic. Furthermore, $\boldsymbol{I}$ respect the opinions of those that disagree with the essay's purpose. (C4)

The assumption concerning a personal and reflective tonality in the participants' E2 has been supported by the post-hoc qualitative content analysis. The post-hoc analysis indicates that the participants tended to use personal reflections more liberally in E2 in comparison to E1. Arguably, reflective discourse facilitates a more ample use of $I$ at the expense of other discursive means of explicit self-mention. If this observation holds true, then it is possible to assume that the change of the most frequent self-mention from we to $I$ is concomitant with the change of the discursive space represented by an argumentative essay to that of the reflective essay, or, at least, a hybrid discursive space that could be referred to as an argumentative essay with elements of reflection. This observation could be further illustrated by excerpt (4) taken from the participant's E2:

(4) When I taught English at the primary school where I worked $\boldsymbol{I}$ could see that a lot of pupils have different kinds of interest, some pupils wanted to write the words and other pupils wanted to speak. When I mixed the groups with pupils who wanted to write and with pupils who liked to speak English I gave them subjects where they could first talk about the subject and after that they could write about it. (P8)

In (4), the participant provides a piece of anecdotal evidence which is related to the teaching practice. The participant uses $I$ in order to give an account of events that happened during the teaching practice rather than elaborating upon the argument. 
Arguably, the discursive function of the self-mention $I$ in (4) is associated with the participant's personal narrative. It seems to be referring to the participant's role as narrator and less to that of an academic writer who is engaged in a logical and well-structured argument, which is expected in a typical argumentative essay (Hyland 1990). Following this line of reasoning, it would be logical to assume that self-mentions, such as $I$, are indirectly involved in the authorial roles and discursive spaces which these roles reflect (Ivanič 1998).

Consequently, by means of the frequently used self-mention $I$, the participants divert from an argumentative discursive space to that of a reflective discursive space. In other words, the participants seem to deviate from the typical genre conventions associated with an argumentative essay which involves a main argument, a counter-argument, and conclusions (Hyland 1990). Arguably, the participants override one or several of the genrerelated conventions of argumentative essay writing ("argument - counter-argument - conclusions") by employing reflective writing, which is marked by the frequently used self-mention $I$. The diversion from the argumentative discursive space to reflective discourse could be assumed to be related to the quality of EFL student writing. This assumption is evocative of the contention made by Helms-Park and Stapleton (2003), who argue that the use of self-mentions might provide an index of the quality of EFL student writing.

\subsubsection{The quantitative differences in the frequency of self-mentions in argumentative essays written by the participants and their controls}

The second research question in this study seeks to establish whether or not there are quantitative differences in the frequency of self-mentions in the corpus of essays written by the participants and their controls. In conjunction with this research question, the application of the one-way analysis of variance (ANOVA) to the means presented in Table 2 reveals that there are no statistically significant differences in the frequency 
of self-mentions used by the participants and the control group, given that the analysis has not yielded statistically significant results at $\mathrm{p}<0.05[\mathrm{~F}(3 ; 36)=0.90, \mathrm{p}=0.45]$. This finding could be taken to indicate that self-mentions are similarly distributed in the corpus of $\mathrm{E} 1$ and $\mathrm{E} 2$ written by the participants and the control group, as illustrated by Figure 4 .

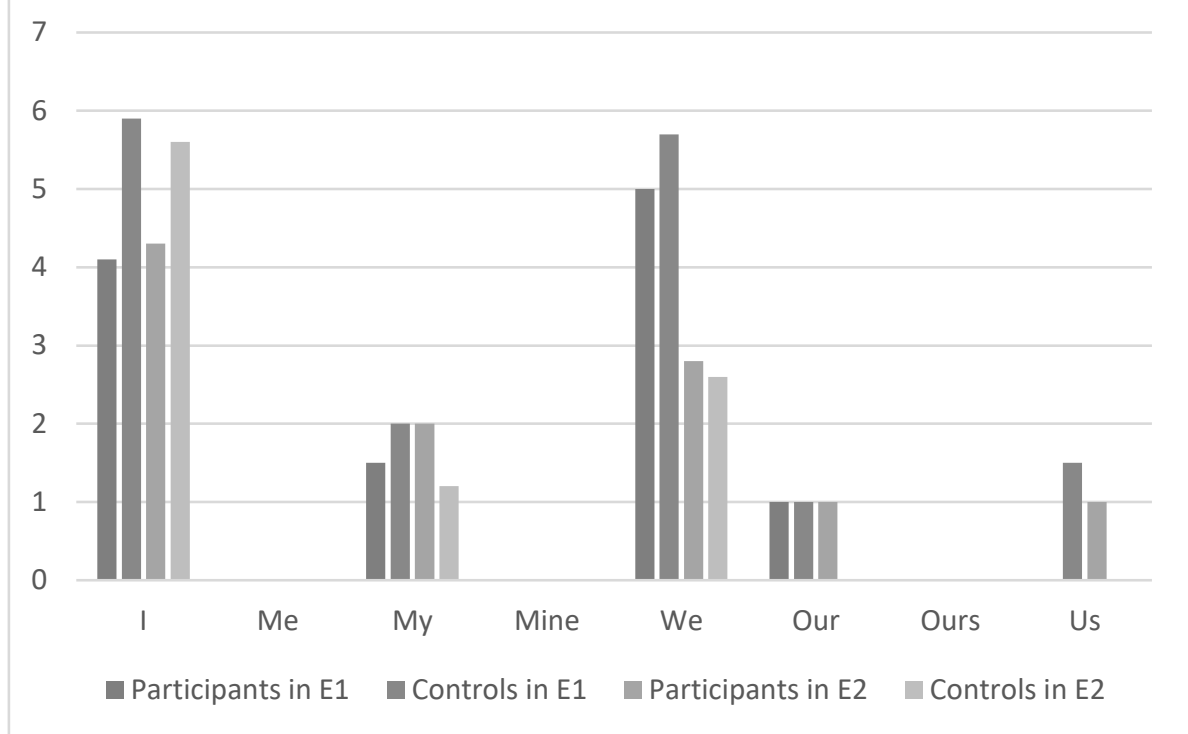

Figure 4

The distribution self-mentions in E1 and E2

It follows from Figure 4 and Tables $2-3$ that in addition to the similarly distributed self-mentions $I, m y$, we, our and us, the participants and their controls did not employ such self-mentions as me, mine and ours. This finding seems to reinforce the similarity between the groups of participants and controls as far as the use of the self-mentions in the corpus is concerned. If there is no statistically significant difference in the use of selfmentions by the participants (pre-service teachers of English), and their controls, (non-teacher students), then it could be argued that the use of self-mentions does not seem to correlate 
with the participants' future teaching profession. It could be assumed that the use of self-mentions in the present corpus is dependent upon the level of EFL proficiency rather than the participants' and controls' university major. In this regard, it should be reiterated that the participants and their respective controls are considered to be on the B1 or B2 level of English proficiency according to the "Common European Framework of Reference for Languages" (Council of Europe, 2011). Obviously, the assumption referring to the influence of the participants' and controls' proficiency levels in English upon the use of self-mentions should be verified in another study that involves a substantial number of participants and, perhaps, a more representative corpus of essays.

In addition to the common level of proficiency in the English language, the similarities in the use of self-mentions by the participants and the control group might be explained by the impact of the Norwegian language, the common L1, upon the strategy of using self-mentions in academic writing in English. In this regard, Monsen and Rørvik (2017) have established that whereas self-mention in academic writing in Norwegian is typically represented by such self-mentions as vi (English: we) and man (English: one, they, it), the first person singular pronoun jeg (English: I) is also frequent in their corpus. Presumably, the compilation of a parallel English-Norwegian corpus associated with self-mentions in academic writing would be necessary to elucidate this observation in a more profound manner. Within the context of the present study, however, it does not seem possible to establish whether or not the participants and their respective controls transferred the use of self-mentions from Norwegian into their argumentative writing in English.

As far as the second research question in this study is concerned, it should be noted that the frequencies of the self-mentions in both in E1 and E2 are relatively low irrespective of whether or not the essays were written by the participants or their controls. For instance, let us consider the mean values of the self-mention $I$ in the corpus, which are 4.1 (participants) and 5.9 (controls) in $\mathrm{E} 1$, and 4.3 (participants) and 5.6 (controls) in 
E2. Following the study conducted by Monsen and Rørvik (2017: 98), the aforementioned means can be described as low, since the frequency of the self-mention $I$ is reported by Monsen and Rørvik (2017) to be a mean $=7, \mathrm{SD}=7.2$, minimum $=0$, maximum $=24$ in the corpus of eight academic essays written by Norwegian L1 EFL student writers.

Taking into account the prior literature (Monsen and Rørvik 2017), I argue that the mean values of self-mentions in the present study can hardly be regarded as high. Consequently, I assume that the self-mentions in this study are neither excessive nor overused by the participants and the control group. On the contrary, the normalised and raw frequency of the self-mentions in the corpus are indicative of the modest use of these discursive means (see Tables $2-3$ ). These findings are in line with the prior studies conducted by Çandarlı, Bayyurt and Mart1 (2015) and Veličković and Jeremić (2020), respectively. Whilst these findings could not be referred to as the avoidance of self-mentions in the sense postulated by Çandarl1, Bayyurt and Mart1 (2015), they are reflective of the participants' and controls' frugal use of self-mentions. These findings seem to support the study conducted by Veličković and Jeremić (2020), where a relatively low frequency of the occurrence of $I$ has been reported. However, the present findings stand in contrast to the study by Alward (2019), who notes the overuse of the self-mention $I$ in academic writing by EFL student writers.

\section{Conclusions}

The study presented in this article sought to elucidate the use of self-mention in two rounds of argumentative essays on EFL didactics written by the group of participants (pre-service EFL teachers) and their controls (non-teacher students). The corpus of the participants' and controls' essays was analysed in order to establish the frequencies of self-mentions as normalised and non-normalised values. The results of the quantitative analysis in SPSS (IBM 2011) and WordSmith (Scott 2008) revealed that the most frequent self-mention in the first round of essays (E1), 
was the first person plural pronoun we. It was found to be similarly distributed in the essays written by the participants and their respective controls. In contrast to E1, the participants and the control group appeared to prefer the use of the first person singular pronoun $I$ in the second round of essays. In this regard, it should be mentioned that no statistically significant differences were found between the groups of participants and controls as far as the use of the self-mentions $I$ and we were concerned. That finding was taken to indicate that the participants and their controls employed self-mentions in a similar manner in their argumentative essay writing.

The results of the data analysis revealed that the participants experienced a change in the self-mentions that they frequently used in the rounds of argumentative essay writing (we in E1 and $I \mathrm{E} 2$, respectively). The change was concomitant with the participants' shift from logically presented and rigorous argumentative writing in $\mathrm{E} 1$ to more reflective writing in E2. A possible explanation for that change could be the fact that in the course structure, E1 was planned to involve feedback from the course teacher, whereas E2 was meant to be written by the participants and controls without the teacher's feedback. Presumably, in a less controlled environment of E2 writing, the participants and their respective controls involuntarily shifted the focus from the argumentative essay scheme "argument - counterargument - conclusions" to a reflective discursive space with elements of argumentation. Arguably, the shift in discursive spaces was concomitant with the participants' and controls' preferences for the self-mention $I$. Based upon the results of the data analysis, it seemed possible to conclude that the EFL student writers' choices of self-mentions reflected their peculiar authorial voices and strategies that were associated with (i) a typical argumentative essay scheme in the first round of essays and (ii) a reflective essay with elements of argumentation in the second round of essays. Obviously, these conclusions should be treated with caution, since the study only involved a small corpus of essays and a limited number of participants $(\mathrm{N}=20$ in total). 
Summarising the present findings, it is possible to offer the following linguo-didactic suggestions. First, given that academic writing can be considered to constitute an integral part of teacher education (Kapranov 2020, Monsen and Rørvik 2017, Shrestha 2020), the use of self-mention in academic writing should be explicitly taught to EFL student writers. Arguably, EFL student writers could benefit from the instructional approach to academic writing that regards self-mentions as an index of genre-appropriate conventions of writing in English. Second, the use of self-mentions should be taught to EFL student writers in conjunction with a parallel corpus of self-mentions found in academic writing in their first language (L1). Presumably, the use of the parallel corpora would facilitate EFL student writers' awareness of discursive means of self-mentions prevalent both in English and in their L1.

\section{Acknowledgements}

The author of this article wishes to acknowledge the 20 students who took part in the study. Their participation is invaluable and highly appreciated. The author expresses his gratitude to the editor and two anonymous reviewers for their comments and suggestions.

\section{References}

Abdelrahim, Azza, Maha Abdelrahim (2020). "Teaching and assessing metadiscoursal features in argumentative writing: A professional development training for EFL teachers". International Journal of Applied Linguistics 30/1: 70-91.

Alward, Ali (2019). "Exploring self-mention in the Yemeni EFL argumentative writing across three proficiency levels". Issues in Language Studies 8/2: 48-60.

Çandarl1, Duygu, Yasemin Bayyurt, Leyla Mart1 (2015). "Authorial presence in L1 and L2 novice academic writing: Cross-linguistic and cross-cultural perspectives". Journal of English for Academic Purposes 20: 192-202. 
Castelló, Montserrat, Anna Iñesta (2012). "Texts as artifacts-in-activity: Developing authorial identity and academic voice in writing academic research papers". In: Montserrat Castelló, Christiane Donahue (eds.). University Writing: Selves and Texts in Academic Societies. Bingley, UK: Emerald group Publishing Limited, 179-200.

Council of Europe (2011). Common European Framework of Reference for languages: Learning, teaching, assessment (CEFR). Language versions. Available at <http://www.coe.int/t/dg4/linguistic/cadreen.asp>. Accessed 1.10.2020.

Davies, Bronwyn, Rom Harré (1990). "Positioning: The discursive production of selves". Journal for the Theory of Social Behaviour 20/1: 43-63.

Drew, Ion, Bjørn Sørheim (2016). English Teaching Strategies: Methods for English Teachers of 10 to 16-year-olds. 3rd edition. Oslo: Samlaget.

Fairclough, Norman (1992). "Discourse and text: Linguistic and intertextual analysis within discourse analysis". Discourse \& Society 3/2: 193-217.

Fløttum, Kjersti (2005). "The self and the others: Polyphonic visibility in research articles". International Journal of Applied Linguistics 15/1: 29-44.

Fløttum, Kjersti (2012). "Variation of stance and voice across cultures". In: Ken Hyland, Carmen Sancho Guinda (eds.). Stance and Voice in Written Academic Genres. London: Palgrave Macmillan, 218-231.

Grigoriev, Ivan, Alexandra Sokolova (2019). "Corpus based analysis of first-person pronouns in research proposals written by Russian students". Journal of Teaching English for Specific and Academic Purposes 7/4: 423-430.

Helms-Park, Rena, Paul Stapleton (2003). "Questioning the importance of individualized voice in undergraduate L2 argumentative writing: An empirical study with pedagogical implications". Journal of Second Language Writing 12/3: 245-265.

Ho, Victor, Cissy Li (2018). "The use of metadiscourse and persuasion: An analysis of first year university students' timed argumentative essays". Journal of English for Academic Purposes 33: 53-68.

Hyland, Ken (1990). "A genre description of the argumentative essay". RELC Journal 21/1: 66-78.

Hyland, Ken (2001). "Humble servants of the discipline? Self-mention in research articles". English for Specific Purposes 20: 207-226. 
Hyland, Ken (2002). "Authority and invisibility: Authorial identity in academic writing". Journal of Pragmatics 34/8: 1091-1112.

Hyland, Ken (2003). "Self-citation and self-reference: Credibility and promotion in academic publication". Journal of the American Society for Information Science and technology 54/3: 251-259.

Hyland, Ken (2005a). "A convincing argument: corpus analysis and academic persuasion". In: Ulla Connor, Thomas Upton (eds.). Discourse in the Professions: Perspectives from Corpus Linguistics. Amsterdam: Benjamins, 87-114.

Hyland, Ken (2005b). "Stance and engagement: A model of interaction in academic discourse". Discourse Studies 7/2: 173-192.

Hyland, Ken (2008). "Persuasion, interaction and the construction of knowledge: Representing self and others in research writing". International Journal of English Studies 8/2: 1-23.

Hyland, Ken (2020). "The communication of expertise: Changes in academic writing". In: Maurizio Gotti (ed.). Linguistic Insights. Bern: Peter Lang, 33-56.

Hyland, Ken, Philip Shaw (2016). The Routledge handbook of English for academic purposes. London: Routledge.

Hyland, Ken, Polly Tse (2004). "Metadiscourse in academic writing: A reappraisal". Applied Linguistics 25/2: 156-177.

IBM (2011). IBM SPSS Statistics for Windows, version 20.0. New York: IBM Corp.

Ivanič, Roz (1998). Writing and Identity: The Discoursal Construction of Identity in Academic Writing. Amsterdam - Philadelphia: John Benjamins.

Kapranov, Oleksandr (2019). "Discourse markers in argumentative essays in EFL by Norwegian pre-service primary school teachers". In: Christoph Haase, Natalia Orlova (eds.). English Language Teaching through the Lens of Experience. Newcastle upon Tyne: Cambridge Scholars Publishing, 83-100.

Kapranov, Oleksandr (2020). "The use of discourse markers in academic writing in English by in-service primary school teachers". Prague Journal of English Studies 9/1: 197-229.

Lachowicz, Dobroslaw (1981). "On the use of the passive voice for objectivity, author responsibility and hedging in EST". Science of Science 2/6: 105-115.

McGrath, Lisa (2016). "Self-mentions in anthropology and history research articles: Variation between and within disciplines". Journal of English for Academic Purposes 21: 86-98. 
Monsen, Marte, Sylvi Rørvik (2017). "Pronoun use in novice L1 and L2 academic writing". Oslo Studies in Language 9/3: 93-109.

Mühlhäusler, Peter, Rom Harré (1990). Pronouns and People: The Linguistic Construction of Social and Personal Identity. Oxford: Blackwell.

Negretti, Raffaella, Maria Kuteeva (2011). "Fostering metacognitive genre awareness in L2 academic reading and writing: A case study of pre-service English teachers". Journal of Second Language Writing 20/2: 95-110.

Nijakowska, Joanna (2013). "Politeness in written academic discourse: A case of EFL methodology textbooks". In: Danuta Gabryś-Barker, Joanna Bielska (eds.). The Affective Dimension in Second Language Acquisition. Bristol: Multilingual Matters, 177-193.

Scott, Mike (2008). Wordsmith Tools: Version 4.0: Single-user Licence.

Shrestha, Prithvi N. (2020). Dynamic Assessment of Students' Academic Writing. Cham: Springer.

Szczygłowska, Tatiana (2020). "Creating the authorial self in academic texts: Evidence from the expert's style of writing". English Studies at NBU 6/1: 69-94.

Tang, Ramona, Suganthi John (1999). "The 'I' in identity: Exploring writer identity in student academic writing through the first person pronoun". English for Specific Purposes 18: 23-39.

Thompson, Celia, Janne Morton, Neomy Storch (2016). "Becoming an applied linguist: A study of authorial voice in international PhD students' confirmation reports". Australian Review of Applied Linguistics 39/2: 139-157.

Torres, Joel Mayo, Ericson Olario Alieto (2019). “Acceptability of Philippine English grammatical and lexical items among pre-service teachers". The Asian EFL Journal 21/2.3: 158-181.

Veličković, Marta, Jelena Danilović Jeremić (2020). "Taking a stand: Stance strategies in L1 Serbian English learners' expository essays". Journal of Teaching English for Specific and Academic Purposes: $147-158$.

Walková, Milada (2019). "A three-dimensional model of personal selfmention in research papers". English for Specific Purposes 53: 6073.

Wang, Yan, Mark Evan Nelson (2012). "Discursive construction of authorial voice in English book reviews: A contrastive analysis". Hong Kong Journal of Applied Linguistics 14/1: 1-24. 
Yoon, Hyung-Jo (2020). "Interactions in EFL argumentative writing: effects of topic, L1 background, and L2 proficiency on interactional metadiscourse". Reading and Writing: 1-21.

Yoon, Hyung-Jo (2017). "Textual voice elements and voice strength in EFL argumentative writing". Assessing Writing 32: 72-84.

Zareva, Alla (2013). "Self-mention and the projection of multiple identity roles in TESOL graduate student presentations: The influence of the written academic genres". English for Specific Purposes 32/2: 72-83.

Zhang, Fengjuan, Ju Zhan (2020). "Understanding voice in Chinese students' English writing". Journal of English for Academic Purposes 45: 1-9.

Zhao, Cecilia Guanfang (2013). "Measuring authorial voice strength in L2 argumentative writing: The development and validation of an analytic rubric". Language Testing 30/2: 201-230.

Oleksandr Kapranov

ORCID iD: 0000-0002-9056-3311

Western Norway University

of Applied Sciences

Postboks 7030

5020 Bergen

Norway

oleksandr.kapranov@hvl.no 